\title{
SOSIALISASI GREEN PACKAGING DI DESA DARMAWANGI KECAMATAN TOMO KABUPATEN SUMEDANG
}

\section{GREEN PACKAGING SOCIALIZATION IN DARMAWANGI VILLAGE, TOMO SUBDISTRICT REGENCY OF SUMEDANG}

\author{
Yosini Deliana $^{*}$, Sri Fatimah ${ }^{1}$, Lucyana Trimo ${ }^{1}$, Mohamad Djali ${ }^{2}$, Endah Wulandari ${ }^{2}$ \\ ${ }^{1}$ Departemen Sosial Ekonomi, Fakultas Pertanian, \\ Universitas Padjadjaran, Jl Raya Jatinangor KM 21 Sumedang Jawa Barat \\ ${ }^{2}$ Departemen Teknologi Industri Pangan, Fakultas Teknologi Industri Pertanian, \\ Universitas Padjadjaran, J1 Raya Jatinangor KM 21 Sumedang Jawa Barat \\ Emai1*: y.deliana@gmail.com \\ (Diterima 13-12-2020; Disetujui 2-1-2021)
}

\begin{abstract}
ABSTRAK
Untuk mengatasi sampah plastik, pemerintah Indonesia sudah menerbitkan Peraturan Presiden Nomor 83 Tahun 2018. Juga Peraturan Daerah Bandung No. 17 tahun 2018 tentang pengurangan penggunaan kantong plastik. Sejumlah strategi sudah dilakukan, namum sampai saat ini pelaksanaanya belum berjalan dengan optimal. Mitra diberdayakan dengan pelatihan pentingnya green packaging (kemasan ramah lingkungan) untuk mengurangi sampah plastik. Harapannya apabila mitra memiliki kekompakan dalam mengelola usahanya, motivasi yang kuat dalam berwirausaha, memiliki produk yang potensial untuk dipasarkan, mengetahui kemasan yang ramah lingkungan (green packaging), dan mengetahui tarket pasar konsumen konsumen hijau, selanjutnya ditingkatkan terus produknya menuju green produk. Penanganan isu lingkungan industri kertas melalui penggunaan bahan dasar kertas nonkayu menjadi hal yang menarik dengan memanfaatkan tanaman tahunan atau sisa tanaman agrikultur untuk digunakan sebagai bahan dasar kertas dan pulp. Pengabdian kepada masyarakat di desa Darmawangi Kecamatan Tomo Kabupaten Sumedang tentang green packaging dimulai dengan memberikan materi "Sosialisasi Green Packaging untuk Produk Sabun Mangga" kepada kelompok wanita petani di Desa Darmawangi. Materi diberikan secara daring pada Webinar Ketahanan dan Keamanan Pangan pada tanggal 17 Juni 2020., dilanjutkan dengan pemberian materi tentang motivasi kewirausahaan. Evaluasi kegiatan PPM tentang kemasan green packaging di Desa Darmawangi menunjukkan antusiasme yang baik dan peningkatakan sekitar 75\% pemahaman akan kemasan ramah lingkungan.
\end{abstract}

Kata kunci: Kemasan, Ramah Lingkungan, Darmawangi

\section{ABSTRACT}

To overcome plastic waste, the Government of Indonesia has issued Presidential Regulation No. 83 of 2018. Also Bandung Regional Regulation No. 17 of 2018 on reducing the use of plastic bags. A number of strategies have been carried out but until now the implementation has not run optimally. Partners are empowered with training on the importance of green packaging to reduce plastic waste. It is hoped that if the partner has a cohesiveness in managing his business, a strong motivation in entrepreneurship, has a potential product to be marketed, know the green packaging and know the tarket of the green consumer consumer market, then improved the product to green products. Handling the environmental issues of the paper industry through the use of non-wood paper base material becomes an interesting thing by utilizing annual crops or agricultural plant residues to be used as the basic material of paper and pulp. Community service in Darmawangi village, Tomo District, Sumedang regency about green packaging began by giving the material "Socialization of Green Packaging for Mango Soap Products" to a group of women farmers in Darmawangi Village. The material was given online at the Food Security and Security Webinar on June 17, 2020, followed by material on entrepreneurial motivation. Evaluation of PPM activities 


\section{SOSIALISASI GREEN PACKAGING DI DESA DARMAWANGI KECAMATAN TOMO \\ KABUPATEN SUMEDANG}

Yosini Deliana, Sri Fatimah, Lucyana Trimo, Mohamad Djali, Endah Wulandari

on green packaging in Darmawangi Village showed good enthusiasm and the increase of about $75 \%$ understanding of environmentally friendly packaging.

Keywords: Green Packaging, Darmawangi, Bags

\section{PENDAHULUAN}

Antara riset dan mitra saling timbal balik. Hasil riset menunjang dalam peningkatan kualitas, pemasaran produk, perluasan pasar, informasi pasar, diversifikasi produk sehingga pendapatan KWT di Desa Darmawangi Kecamatan Tomo Kabupaten Sumedang meningkat. Demikian pula halnya dengan pemberdayaan mitra dalam meningkatkan pendapatan juga memperhatikan ramah lingkungan. Seperti kita ketahui bahwa banyak sekali pencemaran di muka bumi ini, salah satunya karena sampah, ratarata tiap tahun 8 juta ton atau 3 persen dari total sampah plastik berakhir di laut (Setyowati \& Mulasari, 2013).

Kepala Sidang PBB tentang Lingkungan (United Nations Envirinment Assembly/ UNEA) ke - 4, Siim Kiisler, dalam pidatonya awal Maret 2019 di Nairobi, menyerukan agar semua Negara melakukan perubahan untuk mendapatkan lingkungan yang bersih. Lingkungan yang kotor disebabkan oleh pencemaran udaran dan sampah, terutama sampah plastik yang tidak bisa terurai di dalam tanah. Persentase komposisi sampah plastik dibandingkan jenis sampah lainnya meningkat dari tahun ke tahun tterlihat dari Gambar 1.

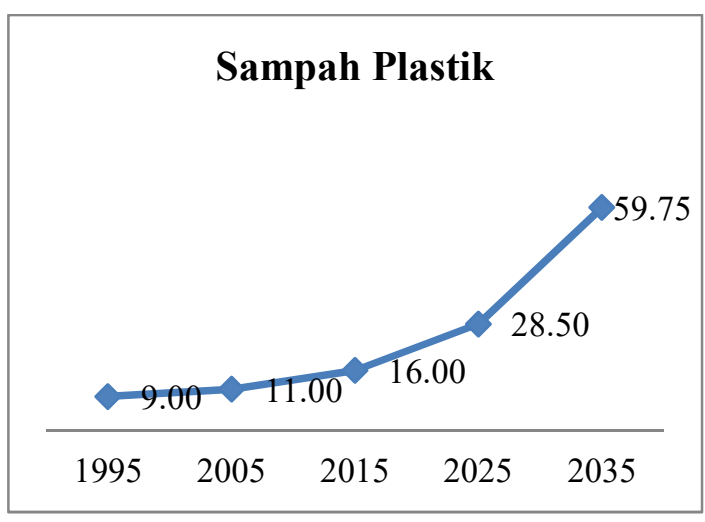

Gambar 1. Persentase Komposisi Sampah Plastik

Untuk mengatasi sampah plastik, Pemerintah Indonesia sudah menerbitkan Peraturan Presiden Nomor 83 Tahun 2018. Juga Peraturan Daerah Bandung No. 17 tahun 2018 tentang pengurangan penggunaan kantong plastik. Sejumlah strategi sudah dilakukan akan tetapi sampai saat ini pelaksanaanya belum berjalan dengan optimal.

Mitra diberdayakan dengan pelatihan pentingnya green packaging (kemasan ramah lingkungan) untuk mengurangi sampah plastik. Harapannya apabila mitra memiliki kekompakan dalam mengelola usahanya, motivasi yang kuat dalam berwirausaha, memiliki produk yang potensial untuk dipasarkan, 
mengetahui kemasan yang ramah lingkungan (green packaging) dan mengetahui tarket pasar konsumen konsumen hijau, selanjutnya ditingkatkan terus produknya menuju green produk, dibina dan adanya pendampingan dari pihak akademisi, pemerintah,stakeholder maka tidak menutup kemungkinan bisa ekspor (Karuniastuti, 2013).

\section{METODE PENELITIAN}

Kegiatan ini dilaksanakan pada bulan Juni-September 2020 di KWT Desa Darmawangi, Kecamatan Tomo, Sumedang Jawa Barat. Pelaksanaan kegiatan ini terbagi dalam dua tahap yaitu pelatihan dan pendampingan pengembangan usaha. Uraian kegiatan tersebut adalah:

1. Pembinaan usaha, dalam kegiatan ini masyarakat di dorong untuk membuat inovasi produk. Sebuah inovasi dapat diterima dan digunakan oleh peserta melalui sebuah proses adopsi yaitu :

\section{a. Awareness (kesadaran)}

Masyarakat sadar semakin sulitnya mencari pekerjaan karena mereka tidak memiliki kompetensi dan keterampilan khusus, sehingga mereka sangat membutuhkan cara yang mudah dan sederhana untuk mendapatkan

penghasilan tambahan. Mereka juga mengalami secara langsung sulitnya mendapatkan penghasilan tambahan sekarang ini, sedangkan kebutuhan terus bertambah.

\section{b. Interest (ketertarikan)}

Masyarakat mulai paham dan tertarik untuk mengatasi lingkungan. Dengan melestarikan lingkungan dan memanfaatkan produksi buah mangga yang melimpah menjadi produk yang bernilai. Peserta akan mendapatkan penghasilan mandiri,mengurangi pengangguran dan tidak lagi meresahkan masyarakat.

\section{c. Evaluation (evaluasi)}

Masyarakat akan mengevaluasi tindakan apa yang paling mudah, murah serta memungkinkan untuk mengatasi permasalahan lingkungan serta sekaligus menjadi sarana untuk mencoba mencari penghasilan tambahan.

\section{d. Trial (mencoba-coba)}

Masyarakat mencoba membuat produk yang mudah dibuat dengan teknologi tepat guna. Dengan PKM ini peserta akan diajarkan mulai dari mengolah mangga, menjadikan produk buah mangga kering yang lebih tinggi nilai jualnya. 


\section{e. Adoption (menerapkan)}

Pada tahapan ini peserta sudah yakin untuk memproduksi buah mangga kering. Pada tahapan ini juga mereka sudah mulai mencoba untuk menjadikan bisnis produk ini sebagai lahan bisnis dalam mendapatkan penghasilan tambahan.

Adapun rincian metode yang digunakan dalam kegiatan ini sebagaimana dalam Tabel 1.

Tabel 1. Metode Yang Digunakan

\begin{tabular}{|c|c|c|c|}
\hline \multirow[t]{2}{*}{ No } & \multirow[t]{2}{*}{ Kegiatan } & \multicolumn{2}{|c|}{$\begin{array}{c}\text { Keterlibatan dalam } \\
\text { kegiatan }\end{array}$} \\
\hline & & Dosen & Masyarakat \\
\hline 1 & Survey & $\begin{array}{l}\text { Pendamping } \\
\text { an dan } \\
\text { Pengarahan } \\
\text { materi } \\
\text { survey }\end{array}$ & Peserta \\
\hline 2 & Pelatihan & $\begin{array}{l}\text { Pemberian } \\
\text { materi }\end{array}$ & Peserta \\
\hline 3 & $\begin{array}{l}\text { Pendampin } \\
\text { gan }\end{array}$ & $\begin{array}{l}\text { Pendamping } \\
\text { an dan } \\
\text { pengarahan }\end{array}$ & $\begin{array}{l}\text { Pendamping } \\
\text { an program } \\
\text { kegiatan. }\end{array}$ \\
\hline 4 & Evaluasi & $\begin{array}{l}\text { Evaluasi } \\
\text { kegiatan }\end{array}$ & $\begin{array}{l}\text { Membantu } \\
\text { merealisasik } \\
\text { an program } \\
\text { kegiatan }\end{array}$ \\
\hline
\end{tabular}

\section{HASIL DAN PEMBAHASAN}

Deliana et al., 2019 menyatakan bahwa produksi kertas dan pulp menjadi salah satu sektor yang permintaannya paling banyak di industri. Kertas memberikan banyak manfaat bagi manusia di berbagai bidang, di antaranya bidang pendidikan, komunikasi, keamanan, dan higienitas. Namun demikian, industri kertas dan pulp dipandang sebagai industri yang banyak menghabiskan sumber daya alam (kayu dan air), dan juga menjadi salah satu sumber polusi pada lingkungan. Bubur selulosa merupakan bahan mentah utama dalam produksi berbagai jenis kertas dan pulp serta bahan dasar material penyerap dalam produk popok dan sanitasi. Produksi pulp dan kertas yang mengandalkan serat selulosa dari pohon kayu telah menimbulkan dampak negatif pada hutan dan ekosistem lainnya. Pada beberapa negara, konsumsi kertas yang meningkat juga menghasilkan limbah dengan level yang tinggi. Peningkatan permintaan kebutuhan kertas juga meningkatkan tekanan terhadap persediaan sumber daya bahan baku kertas. Kebanyakan konsumsi kertas di dunia utamanya digunakan untuk tujuan kemasan, pencetakan, dan penulisan. Beberapa cara dapat dilakukan untuk mengurangi beban pemenuhan kebutuhan bahan baku kertas dari pohon kayu dan mengurangi laju deforestasi. Saat ini, serat daur ulang digunakan untuk memenuhi produksi kertas kategori kertas koran dan kemasan sebanyak 50\% sedangkan untuk produksi kertas kategori kertas pencetakan dan penulisan hanya 8\%. Penggunaan kertas yang didaur 
ulang sebagai bahan baku produksi kertas dapat menjadi cara mengurangi limbah namun ini masih belum memadai karena peningkatan permintaan kertas di pasar. Pengembangan penggunaan bahan baku lain untuk produksi kertas juga masih memiliki peluang. Tiongkok telah menggunakan serat non-kayu dari limbah agrikultur untuk memenuhi lebih dari 50\% kebutuhan pulp.

Kertas menjadi salah satu komoditas ekspor unggulan non-migas Indonesia yang menyumbangkan volume ekspor terbesar di dunia. Hal ini merupakan peluang pengembangan ekonomi dan sosial, bahkan pengembangan lingkungan dengan memperluas sektor produksi. Komoditas pulp dan kertas memiliki struktur industri yang sangat kuat dibandingkan dengan industri lainnya yang ada di Indonesia. Industri pulp dan kertas tidak mengalami ketergantungan impor bahan baku. Indonesia sebagai produsen pulp dan kertas terbesar ketiga dunia, terus meningkatkan kapasitas produksi guna mengejar tingkat efisiensi. Industri kertas di Indonesia memiliki daya saing yang tinggi di ruang lingkup dunia. Namun demikian, dalam prosesnya industri pulp dan kertas menghadapi beberapa permasalahan yang ada di pasar internasional, seperti kualitas produk, persaingan harga, dan isu lingkungan (Karuniastuti, 2013).

Penanganan isu lingkungan industri kertas melalui penggunaan bahan dasar kertas nonkayu menjadi hal yang menarik dengan memanfaatkan tanaman tahunan atau sisa tanaman agrikultur untuk digunakan sebagai bahan dasar kertas dan pulp. Pengunaan material nonkayu hampir mencapai $10 \%$ untuk produksi pulp dan kertas dunia, termasuk diantaranya jerami, bambu, alang-alang dan lain-lain. Peningkatan kebutuhan kertas dan juga masalah lingkungan menjadi penguatan untuk menghasilkan produk kertas dan pulp berbahan nonkayu. Hal ini juga mengarah pada pengembangan teknologi alternatif pemrosesan pulp dan kertas yang harus mempertimbangkan aspek lingkungan. Serat non-kayu menjadi dapat menjadi salah satu sumber utama untuk industri kertas dan pulp karena kelimpahannya dan nilainya yang ekonomis. Serat nonkayu dapat digunakan untuk berbagai jenis kertas, antara lain kertas untuk penulisan dan pencetakan yang dibuat dari serat non-kayu yang telah mengalami pemutihan, juga kertas untuk kemasan. Kertas berbahan dasar tanaman agrikultur dipandang menjadi cara untuk 


\section{SOSIALISASI GREEN PACKAGING DI DESA DARMAWANGI KECAMATAN TOMO \\ KABUPATEN SUMEDANG \\ Yosini Deliana, Sri Fatimah, Lucyana Trimo, Mohamad Djali, Endah Wulandari}

mengurangi tekanan produksi kertas dari pohon kayu hutan. Selain itu, bahan ini pun memerlukan waktu yang lebih singkat dalam proses pemasakannya sehingga energi, air, dan bahan kimia yang digunakan lebih sedikit. Limbah tanaman agrikultur mejadi sumber alternatif yang kompetitif dan menunjukkan potensi untuk digunakan dalam industri kertas karena tersedia dengan melimpah dan mudah akibat hasil industri pengolahan buah (Setyowati \& Mulasari, 2013). Berbagai kajian terkait pemanfaatan selulosa dari limbah tanaman agribisnis telah banyak dikembangkan. Konsumsi atau pemrosesan industri berbahan buah mangga menyisakan biji mangga yang menjadi limbah tanaman agrikultur dan hal ini kembali menjadi masalah lingkungan. Namun demikian, pemanfaatan biji mangga berpotensi untuk digunakan sebagai bahan dasar pembuatan kertas dan pulp sehingga diharapkan dapat menjadi substitusi alternatif penggunaan selulosa kayu. Biji manga yang menjadi limbah terdiri dari dua komponen yaitu cangkang dan kernel. Cangkang merupakan lapisan terluar biji yang melindungi bagian kernel. Bagian cangkang banyak mengandung selulosa, hemiselulosa, dan lignin sedangkan kernel lebih banyak mengandung pati. Cangkang biji memiliki potensi selulosa yang dapat menjadi bahan pembuatan kertas dan pulp sedangkan kernel memiliki nilai nutrisi sehingga dapat dimanfaatkan untuk diversifikasi pangan. Berdasarkan kajian sebelumnya tentang pemanfaatan biji mangga menjadi kertas, hal ini bukanlah menjadi sesuatu yang sulit untuk dikembangkan di Indonesia. Buah mangga termasuk salah satu keunggulan buah lokal di Indonesia dan merupakan salah satu komoditas pertanian yang memiliki prospek cerah. Indonesia menghasilkan mangga sebanyak 2,2 juta ton pada tahun 2017 dimana, selain konsumsi pribadi.

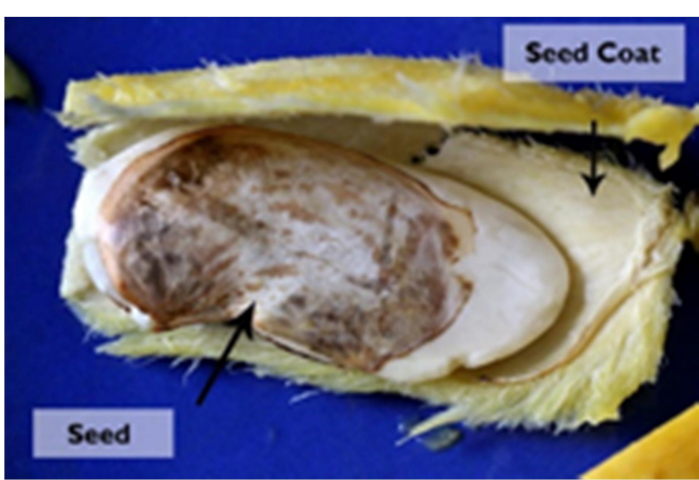

Gambar 2 Komponen biji manga (Silva et al, 2019)

Pengabdian kepada masyarakat (PPM) di desa Darmawangi Kec Tomo Kab Sumedang tentang green packaging dimulai dengan memberikan materi "Sosialisasi Green Packaging untuk 
Produk Sabun Mangga" kepada anggota KWT Desa Darmawangi. Materi diberikan secara daring pada Webinar Ketahanan dan Keamanan Pangan pada tanggal 17 Juni 2020. Pengabdian kepada masyarakat di Desa Darmawangi Kec Tomo Kab Sumedang dilanjutkan dengan pemberian materi tentang motivasi kewirausahaan.

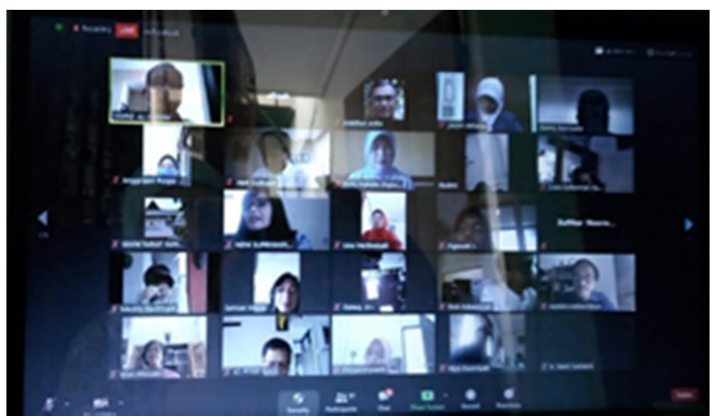

Gambar 3. Pmberian materi green packaging secara daring

Pemberian materi dilakukan secara daring dengan melaksanakan protocol pencegahan penularan covid-19 yaitu dengan menjaga jarak. Kegiatan PPM diikuti oleh anggota KWT Desa Darmawangi sebanyak 18 orang.

Berdasarkan tingkat pendidikan diketahui bahwa golongan pengangguran tertinggi berturut-turut dari yang tertinggi adalah SMK, SMA, dan sarjana. Golongan SMK dan SMA ini termasuk remaja yang aktif dan sewajarnya produktif dengan tenaganya yang kuat. Namun kenyataannya mereka adalah pegangguran terbuka. Pengangguran terbuka artinya angkatan kerja yang sama sekali tidak mempunyai pekerjaan. Mereka tidak berkesempatan untuk berkarya dan berproduksi. Kondisi ini akan menyebabkan mereka menjadi konsumtif dan mengakibatkan pertumbuhan ekonomi negara melambat. Implikasi kenyataan ini akan membawa negara Indonesia menjadi negara konsumtif. Peluang kerja dan pendidikan tampaknya terus berjalan namun membutuhkan waktu yang lama dan berjalan sangat lambat. Oleh karena itu tindakan yang dapat dilakukan mulai saat ini adalah mendidik kewirausahaan. Pada tingkat pendidikan tinggi telah dimasukan mata kuliah kewirausahaan. Diharapkan dapat menumbuhkan semangat dan jiwa kewirausahaan sejak mahasiswa (Santoso et al, 2019)
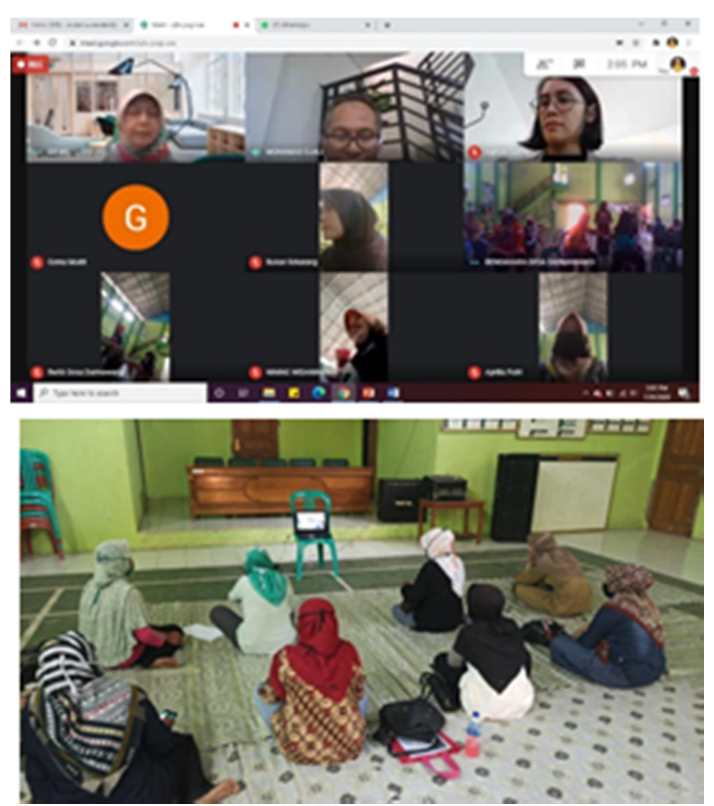

Gambar 4. Pemberian Materi Kewirausahaan secara Daring 


\section{SOSIALISASI GREEN PACKAGING DI DESA DARMAWANGI KECAMATAN TOMO \\ KABUPATEN SUMEDANG \\ Yosini Deliana, Sri Fatimah, Lucyana Trimo, Mohamad Djali, Endah Wulandari}

Evaluasi kegiatan PPM tentang kemasan green packaging sabun mangga di Desa Darmawangi menunjukkan antusiasme yang baik dan peningkatakan pemahaman akan kemasan ramah lingkungan.

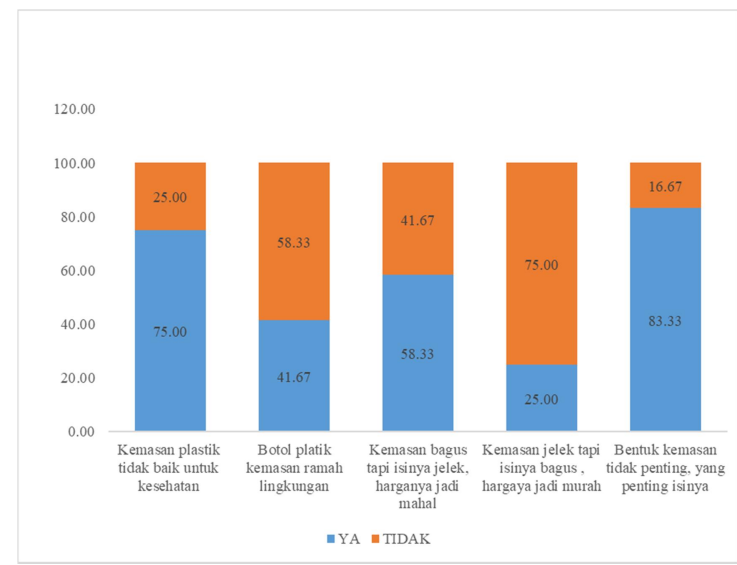

Gambar 5. Pemahaman tentang Kemasan

Dari kegiatan Penyuluhan penggunaan Green Packaging untuk mengurangi sampah plastik yang telah dilaksanakan, didapatkan respon positif dari peserta yang datang. Berdasarkan kuisioner yang telah dibagikan sebelum kegiatan penyuluhan dimulai kepada peserta yang hadir diketahui bahwa $75 \%$ peserta sudah tahu bahwa penggunaan plastik dalam kehidupan sehari-hari sangatlah tidak bagus, baik bagi diri sendiri maupun bagi lingkungan. Namun, masih terdapat peserta yang belum terlalu paham mengenai sampah plastik dan efek penggunaan sampah plastik bagi diri sendiri dan lingkungan.

\section{KESIMPULAN DAN SARAN}

Kegiatan Pengabdian Kepada Masyarakat di Desa Darmawangi yang dilakukan secara daring dapat meningkatkan pemahaman anggota KWT tentang kemasan ramah lingkungan dan menambah motivasi kewirausahaan produk berbasis mangga yang dapat meningkatkan pendapatan rumah tangga anggota KWT Desa Darmawangi.

\section{UCAPAN TERIMA KASIH}

Ucapan terima kasih penulis sampaikan ke pihak DRPMI Universitas Padjadjaran yang telah membiayai kegiatan Pengabdian kepada Masyarakat ini.

\section{DAFTAR PUSTAKA}

Deliana, Y. D., Fatimah, S., Suryadi, E., \& Trimo, L. (2019). Pemberdayaan Kelompok Usaha Bersama KUB dalam Penggunaan Green Packaging untuk Mengurangi Sampah Plastik. Media Kontak Tani Ternak, 1(2), 1. https://doi.org/10.24198/mktt.vli2. 23989

Karuniastuti, N. (2013). BAHAYA PLASTIK TERHADAP KESEHATAN DAN LINGKUNGAN. Swara PatraForum Teknologi, 03(1), 6-14.

Santoso, T., Harianto, S., Winarno, G., \& Febyano, I. (2019). Kewirausahaan Pertanian (1st ed., Vol. 1). PUSAKA MEDIA.

Setyowati, R., \& Mulasari, S. A. (2013). Pengetahuan dan Perilaku Ibu 
Rumah Tangga dalam Pengelolaan Sampah Plastik. Kesmas: National Public Health Journal, 7(12), 562. https://doi.org/10.21109/kesmas.v7i 12.331

Silva, A. P. M., Oliveira, A. V., Pontes, S. M. A., Pereira, A. L. S., Souza Filho, M. de sá M., Rosa, M. F., \& Azeredo, H. M. C. (2019). Mango kernel starch films as affected by starch nanocrystals and cellulose nanocrystals. Carbohydrate Polymers, 211, 209-216. https://doi.org/10.1016/j.carbpol.20 19.02.013 